Mas-Verdu, F., Roig-Tierno, N., Nieto-Aleman, P. A., \& Garcia-Alvarez-Coque, J.-M. (2020). Competitiveness in European Regions and Top-Ranked Universities: Do Local Universities Matter? Journal of Competitiveness, 12(4), 91-108. https://doi.org/10.7441/joc.2020.04.06

\title{
Competitiveness in European Regions and Top-Ranked Universities: Do Local Universities Matter?
}

- Francisco Mas-Verdu, Norat Roig-Tierno, Paula Andrea Nieto-Aleman,
Jose-Maria Garcia-Alvarez-Coque

\section{Abstract}

Based on fuzzy-set qualitative comparative analysis (fsQCA), this paper examines the interactions between the presence or absence of regional and national top-ranked research universities and other innovation-related conditions that foster regional competitiveness in the European Union context. We evaluated the effect of a region's membership in different regional clusters as characterized by the following conditions: inter-firm collaboration in innovation activities, public $R \& D$ expenditure, private $R \& D$ expenditure as well as ranking in the list of the world's top 300 (or top 100) universities. As one region might benefit from the presence of a local top-ranked university and/or from spillover effects from other national universities, we distinguish between the presence of universities within the region or elsewhere in the same country. Our results suggest that some conditions are necessary to achieve the outcome of being a "competitive region," including having at least one top-300-ranked university in the same country (EU member state). Nevertheless, this attribute is not individually sufficient to incur the outcome of regional competitiveness. Our findings support the idea that the closeness of top-ranked universities does not itself guarantee regional competitiveness; instead, having an excellent research university within the same member state is only one of numerous configurations which may lead to a region's success. These results support evidence in recent literature that leading research universities may be geographically connected to a wide network of actors with external knowledge interactions.

Keywords: regional competitiveness, $f$ SQCA, top-ranked universities, inter-firm collaboration, public and private R $\approx D$ expenditure, European Union regions

JEL Classification: O38; I25; I28

Received: July, 2020

1st Revision: October, 2020

Accepted: October, 2020

\section{INTRODUCTION}

Empirical literature on regional innovation provides evidence that research and technology creation encourages significant knowledge spillovers that result in enhanced regional economic development (Goldstein \& Renault, 2004). In general, knowledge is recognized as a key ingredient of the competitiveness of regions, nations, sectors and firms (Huggins \& Johnston, 2009). Uni- 
versities are part of the knowledge system and are expected to promote regional competitiveness (Drucker, 2016). Nevertheless, some authors have argued that it is difficult to define a clear association between a region's dynamics and local knowledge-based infrastructures (Huggins et al, 2008; Howells et al., 2012).

We propose a qualitative comparative approach to evaluate the importance of top-ranked research universities to the competitiveness of regions within the European Union (EU). Numerous authors have explored this question by conceptualizing various university models and examining successful case studies (Trippl et al., 2015). Many of these studies have provided conceptual frameworks towards the definition of the function of the university. Examples of these frameworks include the regional innovation systems approach, the triple helix, as well as social network theory (Fromhold-Eisebith \& Werker, 2013). Still, further study is needed to evaluate whether research universities truly determine regional economic performance. Many regional studies have concentrated on the role of universities in specific countries (Drucker \& Goldstein, 2007; Audretsch et al., 2012). Less attention has been devoted to the contribution of universities across a large sample of European regions. In this article, we consider 266 regions at the NUTS 2 level. Using data on these regions, we seek to determine whether it is necessary for a region to have a top research university to be competitive. To control for "excellence," we use the SCImago ranking of research institutions. This ranking is used to identify the presence or absence of top-ranked universities in each EU region.

Several theories have attempted to explain the contribution of universities to creating an atmosphere conducive to innovation (Drucker \& Goldstein, 2007). As generators, users and disseminators of knowledge, universities may generally be assumed to be key players in regional development. However, it is unclear whether the knowledge generational model is a crucial component of a region's economic dynamics (Gunasekara, 2006). To assess the effect of the university system in different regions we must consider the influence of universities through complex, fluid and iterative knowledge transfer processes (Bramwell \& Wolfe, 2008). A positive impact requires the participation of various actors (such as firms and government) and is influenced by certain enabling conditions considered in the present article. Examples include inter-firm collaboration and R\&D expenditure.

Fuzzy-set qualitative comparative analysis (fsQCA) of EU regions has been carried out to evaluate regional competitiveness outcomes depending on the presence or absence of top research universities in a given EU region. This research also evaluates whether excellent universities are relevant inside the region itself or, alternatively, whether it is enough for them to be located elsewhere in the same country (an EU member state), given the spillover effects of top universities across the whole regional system (Wolfe, 2005; Pinheiro et al., 2012).

The remainder of this article is structured as follows. Section 2 reviews the recent literature on the impact of universities on regional competitiveness as well as introduces a series of propositions to be analyzed using fsQCA. Section 3 presents the data, method and conditions studied using fsQCA. Section 4 discusses the results, while Section 5 offers conclusions and implications for innovation policy derived from the research. 


\section{THEORETICAL BACKGROUND}

\subsection{Universities and regional competitiveness}

In addition to their conventional functions of research and education, universities also promote local development in other ways (Powers, 2004; Pinheiro et al., 2016). Scientific literature as well as policymakers have emphasized the importance of the so-called third mission of the university (Loi \& Di Guardo, 2015, Secundo et al., 2017). This third mission may be particularly relevant in the case of less developed regions with lower institutional density than in more advanced regions (Tödtling \& Trippl, 2005). As generators, stores and disseminators of knowledge, universities can play a crucial role in regional development strategies (Goddard \& Chatterton, 2003). Still, it must be kept in mind that the relationship between the competitiveness of a region and the presence of universities in that region is complex and is subject to various conditioning factors.

Some authors have argued that the contribution of university research and technology output is small compared to other factors. First of all, universities are only one of many organizations in a region; moreover, top-ranked research universities may not be present in many competitive regions. Secondly, research universities tend to measure their performance in terms of the number of scientific publications they produce (Cowan \& Zinovyeva, 2013). This metric may hamper the transformation of scientific knowledge into innovation, since university publications tend to use a codified type of knowledge that is typically less tailored to the needs of local industry than is tacit knowledge. Nevertheless, we formulate the following proposition:

- Proposition P1. The presence of high-performing research universities is a key element for regional development.

\subsection{Universities in the regional innovation system}

The contribution of universities is difficult to distinguish from other influences on a region's economic dynamics (Drucker \& Goldstein, 2007). In addition to the role of universities, recent literature (Mas-Verdu et al., 2016; Garcia-Alvarez-Coque et al., 2017; Garcia-Alvarez-Coque et al., 2019) has highlighted the key role of two other factors concerning regional competitiveness: inter-firm collaboration and the level of public and private R\&D expenditure.

The literature on the so-called learning region (Florida, 1995) and the learning economy (Lundvall \& Johnson, 1994) stresses the relevance of interactive learning within inter-firm and firminstitution networks. For instance, according to De Bresson \& Amesse (1991), "No firm, large or small, can innovate or survive without a network." The presence of conditions that explain why some regions are, or could be, more competitive varies with the socioeconomic and institutional characteristics of the local economy (Sonn \& Storper, 2008, Rodríguez-Pose \& Crescenzi, 2008).

Building alliances among the organizations in a region helps identify and adopt knowledge to generate innovative projects (Bathelt et al., 2004, Miozzo et al., 2016). Several authors (Lasagni, 2012, Tobiassen \& Pettersen, 2018) have shown the positive impact of partnerships between universities and technology centers. Access to knowledge is increased by the collaboration among firms in external networks and links to other regional agents (Jakobsen \& Lorentzen, 2015). 
Public R\&D expenditure and private $R \& D$ expenditure have also been found to be key determinants of regional competitiveness (Marino et al., 2016; Choi \& Lee, 2017). The literature underlines the lack of interchangeability between public and private R\&D expenditure along with the complementary and synergistic relationships between private and public R\&D investment. The high rate of return from investment in $\mathrm{R} \& \mathrm{D}$ has also been highlighted. On the other hand, Van Elk et al. (2015) suggest that public R\&D investments do not automatically stimulate gross domestic product (GDP) or total factor productivity growth. Economic performance seems to be context specific, and apparently depends on institutions and government policies, i. e. the relationship between $\mathrm{R} \& \mathrm{D}$ and regional economic performance is specific to each environment, thus obtaining positive and statistically significant estimates of the rates of return requires models that allow for regional heterogeneity (Luintel et al., 2010).

- Proposition P2. The contribution of universities to regional development cannot be disentangled from other conditions of the regional innovation system.

- Proposition P3. The presence of an inter-firm and firm-institution network (business collaboration) determines regional economic performance.

- Proposition P4. The presence of high levels of private and public R\&D investment determines regional economic performance.

\subsection{Universities and regional proximity}

The incentives for business activity differ from the incentives that drive research in universities. University research is usually required for innovations that can be applied to industry (Cowan et al., 2000). Hence, there is a need for physical and cognitive closeness between knowledgegenerating universities and the firms that turn this knowledge into innovations. However, the knowledge spillovers of research universities can spread beyond a region's borders, so it is not always clear that what is generated inside a given region is relevant for the local firms and society. Feldman \& Desrochers (2003) question the benefits of knowledge spillovers resulting from the proximity of universities to regional clusters. Moreover, studies have shown that the overall economic and innovation performance of regions is generally inversely related to their dependence on the universities located within their boundaries (Huggins \& Johnston, 2009). Certain linkages by certain firms may be more local than others, but there is little conclusive evidence of a distance decay effect across the multiple channels of interaction (Uyarra, 2008). The creation of new knowledge and innovative firms in a region is positively affected by both local and external university knowledge codified in academic patents, even though the positive effect of this external knowledge diminishes with geographical distance (Bonaccorsi et al., 2014).

Though larger firms are more attracted to working with a university because of its strong scientific reputation in a particular area of interest, small firms may demand closer services and consultancy from their local universities. Nevertheless, according to Fromhold-Eisebith \& Werker (2013), remote relationships are also crucial assets for universities. Thus, internationally prominent universities are relevant, even in the development of regions that benefit from knowledge spillovers. Knowledge clusters should not only consist of "local buzz" (Bathelt et al., 2004). Exploring research on the geography of university relationships requires consideration on all fronts, not only on the regional level. Our analysis explores whether universities can be considered to be 
economic development engines on a national or regional level. A regional innovation system can function even when there is no elite university in the region. It depends not only on the functions that the university performs, but also on other characteristics of the learning region or of the regional innovation system.

- Proposition P5. The presence of top research universities in a region encourages the region's economic dynamics, but the role of closer universities may be less determinant than other elements that enhance the regional innovation system.

\subsection{Top research universities}

A criterion is needed to identify top research universities. Neither regions nor universities are identical. Like regions, universities do not form a uniform set (Pinheiro et al., 2012, Harrison \& Turok, 2017). Universities differ not only in strategies and organisation but also in their capacity to influence the area where they are located. In this research, we use a university ranking to distinguish between different types of institutions. We focus on the role of what we term "top universities," thus classified due to their research performance. The number of excellent universities located in the EU depends on the definition of excellence based on meaningful criteria for regional analyses. We used the SCImago ranking to assess universities. Several authors have discussed the methodological, conceptual and statistical issues related to university rankings (Van Raan, 2005; Paruolo et al., 2013). Olcay \& Bulu (2016) showed that few rankings consider indicators that measure industry income derived from knowledge transfer activities. There are also discrepancies in geographical coverage. Universities with high research standards are crucial for opening up knowledge spaces that address both global competition and regional development (Harrison \& van Turok, 2017).

The advantage of the SCImago ranking is its comprehensive coverage, which enables identification of the top 1,000 world universities in terms of published research. We found out that top universities are concentrated in a small number of EU member states. Whilst 18 universities (spread across 15 out of 266 NUTS 2 regions) are ranked amongst the world's top 100 institutions, they are located in just seven EU member states. Broadening the search to the top 300 universities reveals 99 top universities in 74 regions across 13 EU member states (map 1).
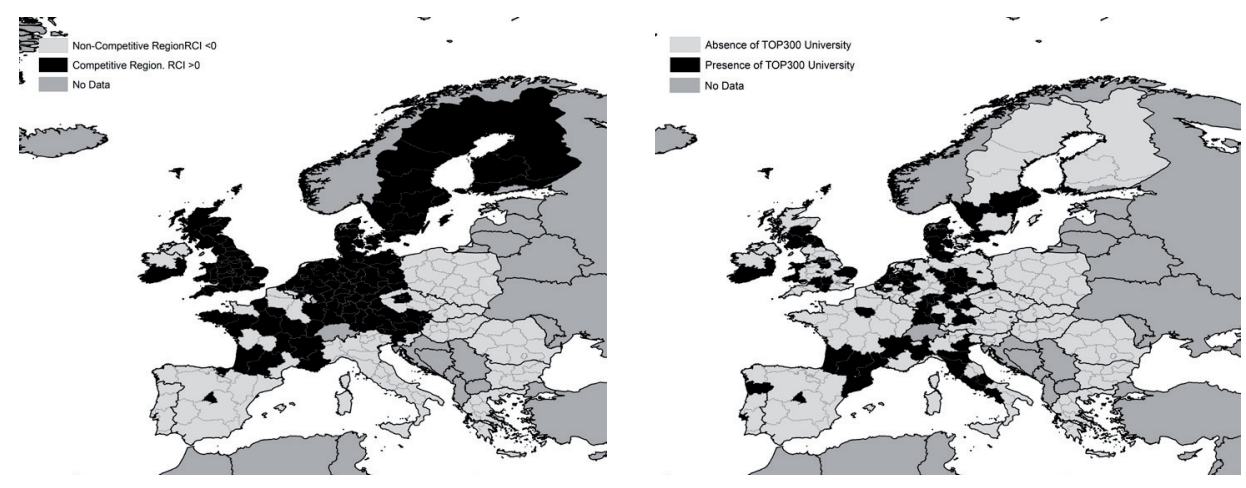

Fig. 1 - EU regions with the Regional Competitiveness Index $>0$ (left) and Regional presence of top research universities (right). Source: own research 


\section{RESEARCH OBJECTIVE, METHODOLOGY AND DATA}

\subsection{Method: fuzzy-set qualitative comparative analysis (fsQCA)}

The methodological foundations of qualitative comparative analysis (QCA) were primarily developed by Ragin $(1987,2008)$. QCA is a set-theoretical method based on the assumption that the influence of a collection of elements on a specific outcome depends on how those elements are combined. Fiss (2007) explains that the use of traditional regression analysis can be problematic in observing equifinality in cases where researchers want to know the configurations of variables that define an outcome (or the absence of that outcome) and not the marginal effects of individual variables that, in practice, cannot be isolated. Multicausality, or the idea that a phenomenon can be caused by two or more conditions and by different combinations of conditions, is a core element of this methodology. QCA uses Boolean logic to establish configurational relationships (Ragin, 2008). An early version of QCA (crisp-set qualitative comparative analysis, or csQCA) only admitted absolute values for conditions ( 0 and 1$)$. These binary values are often unsuitable to represent reality. The version used in this research, namely fsQCA (Ragin, 2008), works with fuzzy values of conditions, ranging between 0 and 1 . These fuzzy values indicate a region's degree of membership in the sets of the proposed conditions or outcome (Thomann \& Maggetti, 2020). According to García-Alvarez-Coque et al. (2019) and Greckhamer et al. (2018), this methodology is useful for dealing with complex causality in regional analysis.

The fsQCA method presented in this article was used to compare cases to identify the paths that lead to a certain outcome, namely regional competitiveness (C-REG).

\subsection{Causal conditions and outcome}

We are interested in the combinations, or causal configurations, of innovation conditions that explain why some regions are, or could be, more competitive. Drawing on the literature review in Section 2, the first condition considered in this study is the presence of a top university, defined here by its position in a well-established ranking. As discussed in the previous section, the recent literature (Domenech et al., 2016; García Álvarez-Coque et al., 2019) also highlights the relevance of two other conditions for regional competitiveness. These are the existence of a certain degree of business collaboration in innovation activities and public and private R\&D expenditure.

In the following sub-sections, the method that we followed to evaluate these conditions for the outcome of interest, which we denote "competitive region" (C-REG), is described. There is evaluated the effect of a region's membership in different regional clusters characterized by the following conditions: inter-firm collaboration in innovation activities (FIRM-COL), public $R \& D$ expenditure (PUB-R\&D), private $R \& D$ expenditure (BUS-R\&D) and ranking in the list of the world's top 300 (or top 100) universities. As one region might benefit from the presence of a local excellent university and/or from spillover effects from other national universities, we distinguish between the presence of universities in the region or elsewhere in the same country. The condition EXCEL-REG refers to the presence of excellent universities in a given region, whereas EXCEL-NAT refers to the presence of excellent universities at the national level, regardless of their presence or absence in that specific region. 
To conduct fsQCA, the following steps must be taken: (i) calibrate the raw data into a set, (ii) generate the truth table, (iii) eliminate the logical remainders and (iv) perform the analyses of necessity and sufficiency. Ragin (2008) provides further details of these steps.

To assess membership of a region in the set of competitive regions (C-REG), the following model was evaluated:

$C-R E G=f[P U B-R \& D, B U S-R \& D, F I R M-C O L, E X C E L-R E G, E X C E L-N A T]$

\subsection{Sample, data and calibration}

Several data sources were used for this research. (i) First, geographical data at NUTS level 2 were gathered for 266 European regions. (ii) Second, data on the European Regional Competitiveness Index (RCI) for 2016 were used to evaluate the outcome set membership scores (Map 1). (iii) Third, data on the Regional Innovation Scoreboard (2016) were used to observe the proportion of SMEs that collaborate and the levels of public and private R\&D expenditure. (iv) Finally, SCImago Institutions Rankings (2016) were used to identify the number of top universities in each region.

The calibration procedure transformed the indicators into membership scores for the regions in the condition sets (Ragin, 2008). The thresholds required for calibration are "fully in" (maximum membership score in the condition set), maximum ambiguity (membership score $=0.5$ ) and "fully out" (total absence from the condition set). Table 1 presents the key descriptive statistics and calibration values. The thresholds were set according to the following criteria: for the outcome (C-REG), the 'fully in' membership threshold was set at 1; the "fully out" threshold was set at the value of the regions whose RCI was equal to -1; finally, the point of maximum ambiguity was set at 0 .

The thresholds to calibrate the conditions FIRM-COL, PUB-R\&D and BUS-R\&D were defined, using a benchmarking technique in order to obtain the average values of the most competitive regions and the least competitive regions, as follows. For full membership ("fully in"), we used the average of the 12 regions with an RCI of more than 1 (the most competitive regions). For the full non-membership ("fully out"), we used the average of the 30 regions with an RCI of less than 1 (the least competitive regions). Finally, for the point of maximum ambiguity, we used the average of the 13 regions with an RCI between -0.05 and 0.05 (the intermediate regions).

The criteria referring to the presence of top universities in the focal region and focal member state (EXCEL-REG and EXCEL-NAT) were defined as the presence of excellent universities in the top 300 or top 100 (membership score $=1$ ) and the absence of excellent universities (membership score $=0)$.

Tab. 1 - Calibration thresholds. Source: own research

\begin{tabular}{|l|l|l|l|l|l|l|l|}
\hline $\begin{array}{l}\text { Conditions } \\
\text { Outcome }\end{array}$ & Fully in & $\begin{array}{l}\text { Point of maximum } \\
\text { ambiguity }\end{array}$ & Fully out & Max & Min & Mean (SD) \\
\hline R\&D spending \\
\hline BUS-R\&D & 0.44 & 0.39 & 0.10 & 0.99 & 0.02 & $0.35(0.19)$ \\
\hline
\end{tabular}




\begin{tabular}{|l|l|l|l|l|l|l|}
\hline PUB-R\&D & 0.29 & 0.19 & 0.14 & 1.00 & 0.01 & $0.22(0.12)$ \\
\hline Business collaboration & 0.16 & 0.88 & 0.00 & $0.36(0.22)$ \\
\hline FIRM-COL & 0.70 & 0.39 & \multicolumn{5}{l|}{} \\
\hline Excellent universities \\
$\begin{array}{l}\text { EXCEL- } \\
\text { REG and EX- } \\
\text { CEL-NAT }\end{array}$ & $\begin{array}{l}\text { Dichotomous conditions. Presence (1) or absence (0) of a university in the top } \\
100 \text { or } 300 \text { in the region and member state, respectively. }\end{array}$ \\
\hline $\begin{array}{l}\text { Regional Competitiveness Index } \\
\text { C-REG }\end{array} 1$ & 0 & -1 & 1.21 & -1.50 & $-0.04(0.68)$ \\
\hline
\end{tabular}

Two rounds of fsQCA were carried out to explore the results with two excellence thresholds for EXCEL-REG and EXCEL-NAT. In the first analysis, the excellence threshold was held by a university ranked amongst the world's top 300. The other analysis used a stricter threshold, where the university was required to be ranked amongst the world's top 100 (Rounds of fsQCA with more flexible definitions were also performed -top 200 and top 500-. The results are available upon request. They generally support our findings for the top 100 and top 300). We evaluated the relevance of university excellence using the presence (or absence) of universities ranked in the world's top 100 and 300 in the region and in the member state.

\subsection{Evaluating necessity and sufficiency}

FsQCA can be used to identify the conditions or configurations that are necessary and sufficient for a region to be classed as competitive (C-REG). Necessary conditions are conditions that are normally required to produce the outcome. Yet, that may not be enough to produce the outcome by themselves. In contrast, sufficient configurations (also referred to as "recipes" or "combinations" of conditions) generally produce the outcome. However, a sufficient configuration may not be the only path to the outcome. Necessity and sufficiency can be evaluated using the consistency and coverage scores defined by Ragin (2008).

Consistency of necessity reflects whether the outcome is consistently a subset of the set of cases in which a condition is present. As a threshold for consistency of necessity, we take the value 0.9, based on the indications of Schneider \& Wagemann (2012). A consistency score above this threshold suggests that the condition is necessary for the outcome to occur. In the case of sufficient conditions, consistency refers to the percentage of causal configurations of a similar composition that result in the same outcome (Ragin, 2008). A condition is normally considered sufficient for an outcome if the consistency value is greater than 0.8 (Schneider \& Wagemann, 2012). A low consistency value reflects a weak subset relationship, so the specific proposition is not supported. Coverage supplies further information on the empirical relevance of the necessary and sufficient conditions. As the necessary conditions, coverage reflects empirical triviality, indicating that the set of conditions is not larger than the set of outcomes. For the sufficient conditions, the coverage determines the proportion of cases where the outcome is represented by a particular configuration of conditions (Ragin 2008). Unlike configurations with low consistency values, configurations with low coverage values may still be relevant. 


\section{RESULTS AND DISCUSSION}

\section{Analysis of necessary conditions}

Table 2 presents the results of the necessity analysis. In addition to consistency and coverage, we calculated the relevance of necessity (RoN). This value indicates the degree of triviality of the condition (Schneider \& Wagemann, 2012).

Tab. 2 - Analysis of necessary conditions for a region that belongs to the 'competitive region' set. Source: own research

\begin{tabular}{|l|c|c|c|}
\hline \multicolumn{3}{|l|}{} & \multicolumn{3}{|l|}{ Ratios for validation of necessity of certain conditions } \\
\hline & $\begin{array}{c}\text { Consistency } \\
\text { of necessity }\end{array}$ & $\begin{array}{c}\text { Coverage } \\
\text { of necessity }\end{array}$ & $\begin{array}{c}\text { Relevance } \\
\text { of necessity }\end{array}$ \\
\hline Presence of: & 0.753 & 0.699 & 0.738 \\
\hline PUB-R\&D & 0.804 & 0.782 & 0.812 \\
\hline BUS-R\&D & 0.935 & 0.676 & 0.576 \\
\hline PUB-R\&D or BUS-R\&D & 0.622 & 0.862 & 0.927 \\
\hline R\&D & 0.718 & 0.869 & 0.915 \\
\hline FIRM-COL & 0.411 & 0.740 & 0.909 \\
\hline EXCEL-REG (TOP 300 university) & 0.927 & 0.600 & 0.421 \\
\hline EXCEL-NAT (TOP 300 university) & 0.103 & 0.916 & 0.995 \\
\hline EXCEL-REG (TOP 100 university) & 0.775 & 0.738 & 0.775 \\
\hline EXCEL-NAT (TOP 100 university) &
\end{tabular}

Note: Calculated using the R package 'Set Methods' (Medzihorsky et al., 2016). PUB-R\&D and BUS-R\&D denote public and private R\&D investment, respectively. FIRM-COL refers to the percentage of firms that collaborate in innovation activities. EXCEL-REG and EXCEL-NAT indicate the presence and absence of top-ranked research universities.

Two potentially necessary conditions explain the presence of the outcome competitive region. The first is the presence in the region of at least one of the two forms of R\&D expenditure: public or private (consistency of necessity $=0.935$ ). The second is the presence in the member state of at least one top university ranked in the top 300 (consistency of necessity $=0.927$ ). It is, therefore, unlikely that a region will be competitive if one of these necessary conditions is missing. This finding does not mean that these conditions are sufficient by themselves. For example, eight member states with at least one non-competitive region have a university ranked in the SCImago top 300 .

\section{Analysis of sufficient conditions.}

The sufficiency analysis shows the causal configurations that lead to the presence of the outcome "competitive region" (Table 3). The results are taken from the parsimonious solution. In Model 1 , the presence of PUB-R\&D and BUS-R\&D were explored independently. Model 2 is more demanding because the presence of both types of R\&D spending was jointly evaluated. Model 1 explored 32 potential configurations, and Model 2 explored 16 potential configurations. After 
applying the consistency cut-offs, three configurations were selected for Model 1 and two configurations were selected for Model 2.

Tab. 3 - Recipes for the outcome "competitive region" presence of innovation conditions in EU regions. Source: own research

\begin{tabular}{|c|c|c|c|c|c|c|c|c|}
\hline & \multicolumn{3}{|c|}{ Model 1} & \multicolumn{2}{|c|}{ Model 2} & \multicolumn{3}{|c|}{ Model 3} \\
\hline Conditions & a & $\mathrm{b}$ & c & $\mathrm{a}$ & $\mathrm{b}$ & $\mathrm{a}$ & $\mathrm{b}$ & $\mathrm{c}$ \\
\hline Private $R \& D$ spending & $\bullet$ & & $\bullet$ & & & & & \\
\hline Public R\&D spending & & & $\bullet$ & & & & & \\
\hline $\begin{array}{l}\text { Private } R \& D \text { spending } \\
\text { and public } R \& D \text { spend- } \\
\text { ing }\end{array}$ & & & & $\bullet$ & & $\bullet$ & $\bullet$ & \\
\hline $\begin{array}{l}\text { Business collaboration in } \\
\text { innovation activities }\end{array}$ & & $\bullet$ & $\bullet$ & & $\bullet$ & $\bullet$ & & $\bullet$ \\
\hline $\begin{array}{l}\text { Top university in region } \\
\text { (top 300) }\end{array}$ & & & & & & & & \\
\hline $\begin{array}{l}\text { Top university in mem- } \\
\text { ber state (top 300) }\end{array}$ & $\bullet$ & $\bullet$ & & & $\bullet$ & & & \\
\hline $\begin{array}{l}\text { Top university in region } \\
\text { (top 100) }\end{array}$ & & & & & & & & \\
\hline $\begin{array}{l}\text { Top university in mem- } \\
\text { ber state (top 100) }\end{array}$ & & & & & & & $\bullet$ & $\bullet$ \\
\hline Consistency & 0.805 & 0.899 & 0.970 & 0.862 & 0.899 & 0.970 & 0.893 & 0.897 \\
\hline Raw coverage & 0.748 & 0.677 & 0.464 & 0.622 & 0.677 & 0.464 & 0.466 & 0.575 \\
\hline Unique coverage & 0.194 & 0.12 & 0.03 & 0.187 & 0.242 & 0.112 & 0.114 & 0.224 \\
\hline $\begin{array}{l}\text { Overall solution consist- } \\
\text { ency }\end{array}$ & 0.807 & & & 0.864 & & 0.870 & & \\
\hline $\begin{array}{l}\text { Overall solution cover- } \\
\text { age }\end{array}$ & 0.901 & & & 0.864 & & 0.802 & & \\
\hline $\begin{array}{l}\text { Frequency threshold; } \\
\text { consistency threshold }\end{array}$ & $1 ; 0.87$ & & & $4 ; 0.871$ & & $1 ; 0.93$ & & \\
\hline
\end{tabular}

Note: As per the notation used by Fiss (2011), • denotes the presence of the condition. Calculated as per Medzihorsky et al. (2016). Shaded cells denote conditions that are not relevant in the corresponding model. Direct expectations: $(1 ; 1 ; 1 ; 1 ; 1 ; 1 ; 1 ; 1)$.

Some traits are common to both Model 1 and Model 2. This observation leads to three preliminary conclusions. First, no single attribute can be considered to be the "winning" combination. Causal configurations consist of a mix of conditions. For example, the presence of business collaboration and the presence of excellent universities in the member state appear consistently in Models 1 and 2. Nevertheless, there are other possible recipes, such as PUB-R\&D and BUSR\&D in Model 2 and PUB-R\&D and BUS-R\&D and FIRM-COL in Model 1. Second, a regional presence of top universities is not a key ingredient in any recipe. Third, the presence of top uni- 
versities in the member state appears in two configurations in Model 1 and in one configuration in Model 2, in combination with business collaboration within the region (see Models $1 \mathrm{~b}$ and 2b). Promoting innovation through R\&D efforts is also part of one of the sufficient configurations (Models 1a and 1c), especially if both public and private R\&D spending is high (Model 2a).

One striking finding is that having top universities at the member state level ranks among the most significant causal drivers of regional competitiveness. In fact, $86 \%$ of regions where the RCI is greater than 0 belong to a member state with at least one university in the top 100 , and $96 \%$ of these regions are located in member states that have at least one university in the top 300 . We can, therefore, deduce that competitive regions are generally located in a member state with top universities. To check the consistency of this result, we proposed and tested Model 3. This model modified Model 2 in that the criterion for excellent universities was constrained to only the top 100 universities in SCImago (Table 3). Model 3 supports the above conclusions. (i) First, it offers several alternative pathways. (ii) Second, it does not include the need for the presence of top universities in the region. (iii) Third, it combines regional firm collaboration with top national universities (Model 3c). (iv) Fourth, it reveals pathways with strong private and public R\&D expenditure, a factor which is sufficient when combined with business collaboration (Model 3a) or with the presence of top universities in the member state (Model 3b).

The selected configurations in Models 1 to 3 for competitive regions cover a substantial percentage of all the regions in which the outcome was shown. Unexplained cases include 13 regions, less than $9 \%$ of the total. These cases provide an opening for further investigation into the competitive conditions in these regions. There are also 17 regions that follow Models 1 to 3 (11\% of the total with high membership scores in the recipes) but that have membership scores of less than 0.5 in the outcome set. Further research is needed to determine why the selected recipes do not seem to be sufficient for the outcome in these regions.

\section{Summary of findings and related propositions}

As summarized in Table 4, a number of this study's findings confirm what has already been highlighted in the empirical literature. For example, the presence of top-ranked universities, at least at the national level, seem necessary for regional competitiveness, which is consequent with P1. What seems interesting is that some sufficient configurations support P2, which states that the university contribution cannot be disentangled from other conditions in the regional innovation system, such as business collaboration (proposition P3) and private R\&D spending (proposition P4).

Tab. 4 - Summary of findings. Source: own research

\begin{tabular}{|c|c|c|c|c|c|c|}
\hline & & \multicolumn{5}{|c|}{ Proposition number } \\
\hline & & P.1 & P.2 & P.3 & P.4 & P. 5 \\
\hline \multicolumn{7}{|c|}{ It is unlikely that a region is competitive if: } \\
\hline • & there is an absence of top universities in the member state. & $\bullet$ & & & & \\
\hline • & there is a regional lack of public or private R\&D spending. & & & & $\bullet$ & \\
\hline \multicolumn{7}{|c|}{ It is likely that a region is competitive if: } \\
\hline • & there is high public and private $\mathrm{R} \& \mathrm{D}$ spending. & & & & $\bullet$ & \\
\hline
\end{tabular}




\begin{tabular}{|c|c|c|c|c|c|}
\hline • & $\begin{array}{l}\text { there is a presence of top universities in the member state } \\
\text { and significant regional private } R \& D \text { spending. }\end{array}$ & $\bullet$ & • & & • \\
\hline • & $\begin{array}{l}\text { there is a presence of top universities in the member state } \\
\text { and significant business collaboration }\end{array}$ & $\bullet$ & • & $\bullet$ & \\
\hline • & $\begin{array}{l}\text { there is high public and private R\&D spending and sig- } \\
\text { nificant business collaboration }\end{array}$ & & • & $\bullet$ & • \\
\hline
\end{tabular}

NOTE: P1: The presence of high-performing research universities is a key element for regional development. P2: The contribution of universities to regional development cannot be disentangled from other conditions of the regional innovation system. P3: The presence of an inter-firm and firm-institution network (business collaboration) determines regional economic performance. P4: The presence of high levels of private and public $R \& D$ investment determines regional economic performance. P5: The presence of top research universities in the region enhances a region's economic dynamics, although the role of universities in closer proximity may be less determinant than other elements that enhance the regional innovation system.

An even more striking finding is that having local top universities does not appear to be a necessary or a sufficient factor in a region's success. This finding is not consistent with proposition P5, which states that proximity matters. We performed a further check by testing QCA models of causal configuration related to a failure for regions to be competitive. The fsQCA revealed that the absence of excellent local universities is relevant for failure when it is combined with a lack of business collaboration. In fact, no region with a negative RCI has a university ranked in the top 100 group. Only 11 regions with a negative RCI have universities amongst the top 300 .

Closeness is relevant when proximity supports other ingredients of innovation. An innovation ecosystem is a set of actors with specific complementary functions assembled by long-term interactions over time (Dorado, 2005). The strength of the system depends on mutual recognition and the stability of relationships between different actors (Villani \& Lechner, 2020). Universities can be innovation enhancers that foster inter-firm cooperation and R\&D activities in collaboration with firms and public agencies. In such contexts, universities occupy a preferential position within their innovation ecosystem for two reasons, with the first of these being the broad spectrum of functions they perform. Along with the traditional function of supplying qualified personnel to public organizations and regional firms, an "entrepreneurial" university model is spreading. These entrepreneurial universities also undertake other functions such as promoting and managing incubators as well as technology and science parks, along with providing new business activities (Clarysse et al., 2014; Cesaroni \& Piccaluga 2016). Second, compared to the high volatility of other components of the system, the enduring nature of universities can make them a node that strengthens interactions among various actors in the ecosystem (Thompson et., 2018).

Highly ranked research universities in a given region may have less demand for partnerships (Laursen et al., 2011). Our findings in this regard are consistent with those of Huggins et al. (2019), who argued that in the situations in which closeness and quality are not associated, quality tends to take precedence. Accordingly, the influence of research universities on innovation systems beyond the regional borders may be substantial, and leading research institutions do not discriminate between actors from inside or outside the region, forming wide geographical networks. 


\section{CONCLUSION}

Regional competitiveness is considered to be a crucial driver of income growth. In this article, the role of universities as fundamental agents in regional innovation systems is analyzed. It has been observed that innovation strategies and university excellence vary across regions and member states. There is high investment in R\&D by the public and business sectors in 190 NUTS 2 regions and in all but one-member state. These findings reflect an extended "standard" innovation strategy across the EU. The presence of collaborating firms, which indicates an "open" innovation strategy, is high in 108 regions and 14 member states. A top university (ranked in the top 300 in the world) is present in 74 out of the 266 regions considered in this study.

The findings may provide a number of lessons that could help regions enhance their competitiveness. The results suggest that some conditions are necessary to achieve the outcome of being a "competitive region." These conditions include high public or private R\&D expenditure as well as having at least one top-300-ranked university in the same country (EU member state). However, each of these attributes itself is not sufficient to cause the outcome of regional competitiveness. These results support the idea that the closeness of top-ranked universities does not guarantee regional competitiveness by itself; instead, having an excellent research university in the same member state is only one of many configurations leading to a region's success. These results support the evidence provided by the recent literature that leading research universities may be geographically connected to a wide network of actors with external knowledge interactions.

Two main strategies emerge from the findings. First, an open innovation strategy could promote business collaboration when coupled with excellent universities. The second strategy is the classical standard innovation strategy that enhances both private and public R\&D expenditure and business collaboration. Even when they do not belong to the high-performing group, universities can still be functional to the extent that they support the other drivers of the regional innovation system. A considerable interregional variation was revealed with regard to the capacity to capitalize on and take advantage of innovation policy. The method proposed in this study could promote participation, dialogue and consultation with local agents (including universities, industry and technology centers) to develop policies adapted to individual regions.

In interpreting our conclusions, two limitations of the study should be noted which may lead to future lines of study to develop our research. The first limitation is the very definition of university excellence. One future line of research would be to widen the scope of excellence to consider different models of universities that include transfer activities and social engagement in addition to research and SCImago ranking. A further possible distinction would be between more collaborative and less collaborative universities, with this determination based on their networks of regional, national and international partnerships. The second limitation relates to the competitiveness conditions assessed in this study. In future research, a broader analysis is recommended to take into account other regional characteristics that determine competitiveness. Examples may include the sector specialization of the region and the presence of knowledge-intensive business services along with other possible regional attributes. 


\section{Acknowledgement}

This research was supported by: (i) grants RTI2018-093791-B-C21 and RTI2018-093791-B-C22 funded by Ministerio de Ciencia, Innovación y Universidades and FEDER. (ii) GV063/19 by Generalitat Valenciana.

\section{References}

1. Audretsch, D., Hülsbeck, M., \& Lehmann, E. (2012). Regional competitiveness, university spillovers, and entrepreneurial activity. Small Business Economics, 39 (3), 587-601. https://doi.org/10.1007/s11187-011-9332-9

2. Bathelt, H., Malmberg, A., \& Maskell, P. (2004). Clusters and knowledge: local buzz, global pipelines and the process of knowledge creation. Progress In Human Geography, 28 (1), 31-56. https://doi.org/10.1191/0309132504ph469oa

3. Bonaccorsi, A., Colombo, M., Guerini, M., \& Rossi-Lamastra, C. (2014). The impact of local and external university knowledge on the creation of knowledge-intensive firms: evidence from the Italian case. Small Business Economics, 43 (2), 261-287. https://doi.org/10.1007/s11187-013-9536-2

4. Bramwell, A., \& Wolfe, D. (2008). Universities and regional economic development: The entrepreneurial University of Waterloo. Research Policy, 37 (8), 1175-1187. https://doi.org/10.1016/j.respol.2008.04.016

5. Cesaroni, F., \& Piccaluga, A. (2016). The activities of university knowledge transfer offices: towards the third mission in Italy. The Journal of Technology Transfer, 41(4), 753-777. https://doi.org/10.1007/s10961-015-9401-3

6. Choi, J., \& Lee, J. (2017). Repairing the R\&D market failure: Public R\&D subsidy and the composition of private R\&D. Research Policy, 46 (8), 1465-1478. https://doi.org/10.1016/j.respol.2017.06.009

7. Clarysse, B., Wright, M., Bruneel, J., \& Mahajan, A. (2014). Creating value in ecosystems: Crossing the chasm between knowledge and business ecosystems. Research Policy, 43 (7), 1164-1176. https://doi.org/10.1016/j.respol.2014.04.014

8. Cowan, R., \& Zinovyeva, N. (2013). University effects on regional innovation. Research Policy, 42 (3), 788-800. https://doi.org/10.1016/j.respol.2012.10.001

9. Cowan, R., David, P., \& Foray, D. (2000). The explicit economics of knowledge codification and tacitness. Industrial and Corporate Change, 9 (2), 211-253. https://doi.org/10.1093/icc/9.2.211

10. DeBresson, C., \& Amesse, F. (1991). Networks of innovators: A review and introduction to the issue. Research Policy, 20 (5), 363-379. https://doi.org/10.1016/0048-7333(91)90063-v

11. Domenech, J., Escamilla, R., \& Roig-Tierno, N. (2016). Explaining knowledge-intensive activities from a regional perspective. Journal of Business Research, 69 (4), 1301-1306. https://doi.org/10.1016/j.jbusres.2015.10.096

12. Dorado, S. (2005). Institutional Entrepreneurship, Partaking, and Convening. Organization Studies, 26 (3), 385-414. https://doi.org/10.1177/0170840605050873 
13. Drucker, J. (2016). Reconsidering the Regional Economic Development Impacts of Higher Education Institutions in the United States. Regional Studies, 50 (7), 1185-1202. https://doi.org/10.1080/00343404.2014.986083

14. Drucker, J., \& Goldstein, H. (2007). Assessing the Regional Economic Development Impacts of Universities: A Review of Current Approaches. International Regional Science Review, 30 (1), 20-46. https://doi.org/10.1177/0160017606296731

15. Feldman, M., \& Desrochers, P. (2003). Research Universities and Local Economic Development: Lessons from the History of the Johns Hopkins University. Industry \& Innovation, 10 (1), 5-24. https://doi.org/10.1080/1366271032000068078

16. Fiss, P. (2007). A set-theoretic approach to organizational configurations. Academy of Management Review, 32 (4), 1180-1198. https://doi.org/10.5465/amr.2007.26586092

17. Fiss, P. (2011). Building Better Causal Theories: A Fuzzy Set Approach to Typologies in Organization Research. Academy of Management Journal, 54 (2), 393-420.

https://doi.org/10.5465/amj.2011.60263120

18. Florida, R. (1995). Toward the learning region. Futures, 27 (5), 527-536.

https://doi.org/10.1016/0016-3287(95)00021-n

19. Fromhold-Eisebith, M., \& Werker, C. (2013). Universities' functions in knowledge transfer: a geographical perspective. The Annals of Regional Science, 51 (3), 621-643.

https://doi.org/10.1007/s00168-013-0559-z

20. García Álvarez-Coque, J., Mas-Verdú, F., \& Roig-Tierno, N. (2017). Technological innovation versus non-technological innovation: different conditions in different regional contexts? Quality \& Quantity, 51 (5), 1955-1967. https://doi.org/10.1007/s11135-016-0394-2

21. Garcia-Alvarez-Coque, J., Mas-Verdú, F., \& Roig-Tierno, N. (2019). Life below excellence: exploring the links between top-ranked universities and regional competitiveness. Studies in Higher Education, 1-16. https://doi.org/10.1080/03075079.2019.1637843

22. Goddard, J. B., \& P. Chatterton. (2003). The Response of Universities to Regional Needs. In Economic Geography of Higher Education: Knowledge, Infrastructure and Learning Regions, edited by F. Boekema, E. Kuypers, and R. Rutten, 19-41. London: Routledge.

23. Goldstein, H., \& Renault, C. (2004). Contributions of Universities to Regional Economic Development: A Quasi-experimental Approach. Regional Studies, 38 (7), 733-746. https://doi.org/10.1080/0034340042000265232

24. Greckhamer, T., Furnari, S., Fiss, P., \& Aguilera, R. (2018). Studying configurations with qualitative comparative analysis: Best practices in strategy and organization research. Strategic Organization, 16 (4), 482-495. https://doi.org/10.1177/1476127018786487

25. Gunasekara, C. (2006). Reframing the Role of Universities in the Development of Regional Innovation Systems. The Journal of Technology Transfer, 31 (1), 101-113. https://doi.org/10.1007/s10961-005-5016-4

26. Harrison, J., \& Turok, I. (2017). Universities, knowledge and regional development. Regional Studies, 51 (7), 977-981. https://doi.org/10.1080/00343404.2017.1328189 
27. Howells, J., Ramlogan, R., \& Cheng, S. (2012). Innovation and university collaboration: paradox and complexity within the knowledge economy. Cambridge Journal of Economics, 36 (3), 703-721. https://doi.org/10.1093/cje/bes013

28. Huggins, R., \& Johnston, A. (2009). The Economic and Innovation Contribution of Universities: A Regional Perspective. Environment and Planning C: Government and Policy, 27 (6), 1088-1106. https://doi.org/10.1068/c08125b

29. Huggins, R., Johnston, A., \& Steffenson, R. (2008). Universities, knowledge networks and regional policy. Cambridge Journal of Regions, Economy and Society, 1 (2), 321-340. https://doi.org/10.1093/cjres/rsn013

30. Huggins, R., Prokop, D., \& Thompson, P. (2019). Universities and open innovation: the determinants of network centrality. The Journal of Technology Transfer, 45 (3), 718-757. https://doi.org/10.1007/s10961-019-09720-5

31. Jakobsen, S., \& Lorentzen, T. (2015). Between bonding and bridging: Regional differences in innovative collaboration in Norway. Norsk Geografisk Tidsskrift - Norwegian Journal of Geography, 69 (2), 80-89. https://doi.org/10.1080/00291951.2015.1016550

32. Lasagni, A. (2012). How Can External Relationships Enhance Innovation in SMEs? New Evidence for Europe. Journal of Small Business Management, 50 (2), 310-339. https://doi.org/10.1111/j.1540-627x.2012.00355.x

33. Laursen, K., Reichstein, T., \& Salter, A. (2011). Exploring the Effect of Geographical Proximity and University Quality on University-Industry Collaboration in the United Kingdom. Regional Studies, 45(4), 507-523. https://doi.org/10.1080/00343400903401618

34. Loi, M., \& Di Guardo, M. (2015). The third mission of universities: An investigation of the espoused values. Science and Public Policy, 42 (6) 855-870. https://doi.org/10.1093/scipol/scv012

35. Luintel, K. B., Khan, M., \& Theodoridis, K. (2010). How robust is the R\&D-productivity relationship? Evidence from OECD countries, (1). WIPO.

36. Lundvall, B. Ä., \& Johnson, B. (1994). The learning economy. Journal of Industry Studies, 1 (2), 23-42. https://doi.org/10.1080/13662719400000002

37. Marino, M., Lhuillery, S., Parrotta, P., \& Sala, D. (2016). Additionality or crowding out? An overall evaluation of public R\&D subsidy on private R\&D expenditure. Research Policy, 45 (9), 1715-1730. https://doi.org/10.1016/j.respol.2016.04.009

38. Mas-Verdú, F., Ortiz-Miranda, D., \& García-Álvarez-Coque, J. (2016). Examining organizational innovations in different regional settings. Journal of Business Research, 69 (11), 5324-5329. https://doi.org/10.1016/j.jbusres.2016.04.132

39. Miozzo, M., Desyllas, P., Lee, H., \& Miles, I. (2016). Innovation collaboration and appropriability by knowledge-intensive business services firms. Research Policy, 45 (7), 1337 1351. https://doi.org/10.1016/j.respol.2016.03.018

40. Olcay, G., \& Bulu, M. (2017). Is measuring the knowledge creation of universities possible? A review of university rankings. Technological Forecasting and Social Change, 123, 153-160. https://doi.org/10.1016/j.techfore.2016.03.029 
41. Paruolo, P., Saisana, M., \& Saltelli, A. (2013). Ratings and rankings: voodoo or science? Journal of The Royal Statistical Society: Series A (Statistics In Society), 176 (3), 609-634.

https://doi.org/10.1111/j.1467-985x.2012.01059.x

42. Pinheiro, R., Benneworth, P., \& Jones, G. A. (2012). Universities and Regional Development: A critical assessment of tensions and contradictions. Routledge: Milton Park and New York.

43. Pinheiro, R., Charles, D., \& Jones, G. (2016). Equity, institutional diversity and regional development: a cross-country comparison. Higher Education, 72 (3), 307-322.

https://doi.org/10.1007/s10734-015-9958-7

44. Powers, J. (2004). R\&D Funding Sources and University Technology Transfer: What Is Stimulating Universities to Be More Entrepreneurial? Research in Higher Education, 45 (1), 1-23. https://doi.org/10.1023/b:rihe.0000010044.41663.a0

45. Ragin, C. (1987). The comparative method. Berkeley: University of California Press.

46. Ragin, C. (2008). Redesigning social inquiry: Fuzzy-sets and beyond. Chicago: University of Chicago Press.

47. Rodríguez-Pose, A., \& Crescenzi, R. (2008). Research and Development, Spillovers, Innovation Systems, and the Genesis of Regional Growth in Europe. Regional Studies, 42 (1), 51-67. https://doi.org/10.1080/00343400701654186

48. Schneider, C. Q., \& Wagemann, C. (2012). Set-theoretic methods for the social sciences: A guide to qualitative comparative analysis. Cambridge University Press.

49. Secundo, G., Elena Perez, S., Martinaitis, Ž., \& Leitner, K. (2017). An Intellectual Capital framework to measure universities' third mission activities. Technological Forecasting and Social Change, 123, 229-239. https://doi.org/10.1016/j.techfore.2016.12.013

50. Sonn, J., \& Storper, M. (2008). The Increasing Importance of Geographical Proximity in Knowledge Production: An Analysis of US Patent Citations, 1975-1997. Environment and Planning A: Economy and Space, 40 (5), 1020-1039. https://doi.org/10.1068/a3930

51. Thomann, E., \& Maggetti, M. (2020). Designing Research with Qualitative Comparative Analysis (QCA): Approaches, Challenges, and Tools. Sociological Methods \& Research, 49 (2), 356-386. https://doi.org/10.1177/0049124117729700

52. Thompson, T., Purdy, J., \& Ventresca, M. (2018). How entrepreneurial ecosystems take form: Evidence from social impact initiatives in Seattle. Strategic Entrepreneurship Journal, 12 (1), 96-116. https://doi.org/10.1002/sej.1285

53. Tobiassen, A., \& Pettersen, I. (2018). Exploring open innovation collaboration between SMEs and larger customers: The case of high-technology firms. Baltic Journal of Management, 13 (1), 65-83. https://doi.org/10.1108/bjm-01-2017-0018

54. Tödtling, F., \& Trippl, M. (2005). One size fits all? Towards a differentiated regional innovation policy approach. Research Policy, 34 (8), 1203-1219. https://doi.org/10.1016/j.respol.2005.01.018

55. Trippl, M., Sinozic, T., \& Lawton Smith, H. (2015). The Role of Universities in Regional Development: Conceptual Models and Policy Institutions in the UK, Sweden and Austria. European Planning Studies, 23 (9), 1722-1740. https://doi.org/10.1080/09654313.2015.1052782 
56. Uyarra, E. (2008). The impact of universities on regional innovation: A critique and policy implications (No. 564). Manchester Business School Working Paper.

57. Van Elk, R., Verspagen, B., Ter Weel, B., Van der Wiel, K., \& Wouterse, B. (2015). A macroeconomic analysis of the returns to public R\&D investments. CPB Netherlands Bureau for Economic Policy Analysis.

58. Van Raan, A. (2005). Fatal attraction: Conceptual and methodological problems in the ranking of universities by bibliometric methods. Scientometrics, 62 (1), 133-143.

https://doi.org/10.1007/s11192-005-0008-6

59. Villani, E., \& Lechner, C. (2020). How to acquire legitimacy and become a player in a regional innovation ecosystem? The case of a young university. The Journal of Technology Transfer. https://doi.org/10.1007/s10961-020-09803-8

60. Wolfe, D A. (2005). The Role of Universities in Regional Development and Cluster Formation. In G. Jones, P. McCarney, \& M. Skolnick (Eds.), Creating Knowledge, Strengthening Nations. Toronto: University of Toronto Press.

\section{Contact information}

prof. Francisco Mas-Verdu, Ph.D.

Universitat Politècnica de València

Spain

E-mail:fmas@upvnet.upv.es

ORCID:0000-0002-0902-9462

prof. Norat Roig-Tierno, Ph.D.

Universitat Politècnica de València

Spain

E-mail:norat.roig@upv.es

ORCID: 0000-0002-7980-3548

Corresponding author

prof. Paula Andrea Nieto-Aleman, Ph.D.

ESIC Business and Marketing School and Universitat Politècnica de València

Spain

E-mail:paula.niet@esic.edu;paunieal@upv.es

ORCID: 0000-0002-9269-5238

prof. José-Maria Garcia-Alvarez-Coque, Ph.D.

Universitat Politècnica de València

Spain

E-mail:jmgarcia@upvnet.upv.es

ORCID: 0000-0002-4334-7843 